Jurnal Luxnos Vol. 4, No. 1, Edisi Januari-Juni 2018

\title{
Hubungan Pemberitaan Injil Dengan Tanggung Jawab Manusia Dalam Kehidupan Sosial Dan Lingkungan Hidup
}

\author{
Anas B. \\ Sekolah Tinggi Teologi Pelita Dunia Tangerang \\ anasb@gmail.com
}

\begin{abstract}
This article will specifically discuss the relationship between the preaching of the Gospel which is the main task of humans in fulfilling His call to carry out God's Great Commission as evangelists in relation to other human responsibilities in integrating the gospel through human relationships with other humans and their environment as a single vessel to carry out this noble calling.
\end{abstract}

Keywords: Bible, Human, Social Life, Environment

Abstrak: Artikel ini akan mengulas secara khusus mengenai hubungan pemberitaan Injil yang menjadi tugas utama manusia dalam memenuhi panggilan-Nya untuk mengemban Amanat Agung Allah sebagai pemberita Injil dalam kaitannya dengan tanggungjawab lain manusia dalam mengintegrasikan Injil itu melalui hubungan manusia kepada manusia lainnya serta lingkungan hidupnya sebagai suatu wadah satusatunya untuk melaksanakan panggilan mulia tersebut.

Kata Kunci: Injil, Manusia, Kehidupan Sosial, Lingkungan hidup

\section{Pendahuluan}

Suatu gerakan pemberitaan Injil merupakan sebuah perintah dari Yesus Kristus sendiri karena itu merupakan tugas yang tidak bisa ditolak atau ditawar-tawar oleh setiap orang yang sudah percaya kepada Yesus Kristus sebagai TUHAN dan Juruselamat. Setiap orang Kristen dengan wajib memberitakan Injil yaitu Injil Kerajaan Sorga atau Injil Kerajaan Allah. Seperti Rasul Paulus katakana bahwa: "Celakalah aku jika akun tidak memberitakan Injil"( I Kor.9:16).

Seperti yang kita perhatikan bahwa pada umumnya gereja-gereja lebih mengutamakan perintah untuk pemberitaan Injil yang biasa disebut Amanat Agung yang dikutip dari Injil Matius 28:18-20. Perintah ini diberikan oleh Yesus sebelum ia naik ke sorga. Dengan kata lain, perintah tersebut merupakan amanat Yesus sendiri untuk dapat melanjutkan misi Yesus yang ia lakukan selama masih hidup dan melayani didunia ini.

Dari ulasan ini akan menjawab pertanyaan-pertanyaan berikut ini: Pertama; Apakah alas an memberitakan Injil Kerajaan Sorga hanyalah terkait dengan perintah Yesus? Kedua; Apakah pemberitaan Injil hanya dapat dilihat dan diterima sebagai sebuah kewajiban berdasarkan perintah Yesus saja? Dalam Perjanjian Baru menceritakan bahwa pelayanan Yesus dimulai dengan pemberitaan Kerajaan Allah dan kita dapat melihat 
dalam Markus 1:14-15; Matius 4:12-17; Lukas 4:14-15. Sesungguhnya Yesus memulai misi-Nya dengan pemberitaan Injil Allah, kata-Nya " Waktunya sudah genap; Kerajaan Allah sudah dekat. Bertobatlah dan percayalah kepada Injil.

Jadi kewajiban untuk memberitakan Injil tidak semata-mata hanya terkait dengan adanya perintah membaptiskan, memuridkan, dan mengajar sebagaimana yang dicatat dalam Injil Matius.28:19-20. Kewajiban itu pertama-tama bersumber dari pemberitaan Yesus Kristus sendiri, Karena Yesus datang untuk memberitakan Injil (adalah berita damai dan sukacita)tentang kerajaan Allah. Bahkan kata-kata memberitakan Injil tidak ada dalam Amanat Agung, tetapi ada dalam misi Yesus Kristus sendiri sebagai pembawa Injil ke dalam dunia.

\section{Metode Penelitian}

Pada penelitian ini, penulis atau peneliti menggunakan pendekatan atau metode kualitatif untuk memperoleh data yang valid guna membangun sebuah teori yang berkaitan dengan tema atau pokok penelitian. Metode kualitatif yang dimaksud adalah mengkaji dan mengelaborasi setiap sumber, informasi dan data-data yang diperoleh dari pustaka.

\section{Hasil dan Pembahasan}

\section{Orang percaya sebagai Pemberita Injil}

Injil berasal dari kata Yunani eungelion yang artinya kabar baik. Penulis Injil Markus memulai tulisannya dengan mengatakan : "Inilah permulaan Injil tentang Yesus Kristus. Anak Allah" (Markus 1:1). Jadi Injil pertama-tama menunjuk kepada Yesus Kristus sendiri. Injil adalah Kabar baik bahwa Allah di dalam Yesus Kristus telah memenuhi janji-janji-Nya kepada Israel, dan bahwa suatu jalan keselamatan telah dibuka bagi semua orang. ${ }^{1}$ Karena Yesus Kristus sendiri juga memberitakan Injil kerajaan Sorga, maka Injil dan Yesus Kristus adalah satu dan bahwa pemberitaan Injil harus di cari dasar dan sumbernya dalam Yesus kristus sendiri. Tema pokok ini hanya focus pada pemberitaan Yesus adalah Injil Kerajaan Sorga atau Injil Kerajaan Allah. ${ }^{2}$ Injil Kerajaan Allah itu tidak sekadar dejelaskan dengan sebuah kata-kata melainkan dengan pelayanan, dengan perbuatan dan dengan tindakan bahwa kuasa Allah hadir melalui dan di dalam diri Yesus Kristus sendiri.

Mengenai Injil Kerajaan Allah yang diberitakan oleh Yesus Kristus bukanlah sesuatu yang bersifat futristik (akan datang) saja melainkan sesuatu yang lebih bersifat presentik (masa kini). Hal ini nampak dari pelayanan Yesus Kristus ketika Ia melakukan

1 J.D. Douglas (Penyunting umum), Ensiklopedi Alkitab Masa Kini, Jilid 1, terj.Tim penerjemah Yayasan Komunikasi Bina Kasih, Jakarta:Yayasan Bina Kasih, 2002,435; Gerald O'Collins dan Edward G. Farrugia, Kamus Teologi, Yogyakarta: Kansius,1996,117.

2 Dalam pengunaan kata Kerajaan Allah dan Kerajaan Sorga secara bervariasi untuk menjelaskan mengenai kata yang sama ditulis oleh Matius kepada orang Yahudi memakai istilah Kerajaan Sorga, karena orang yahudi tidak perna berani menyebut nama Allah. Tetapi Markus dan Lukas memakai istilah Kerajaan Allah, dengan memiliki arti sama dengan Kerajaan Sorga tetapi lebih gampang dimengerti orang yang bukan Yahudi. 
mujizat mengusir setan. "Tetapi jika Aku mengusir setan dengan kuasa Allah, maka sesungguhnya Kerajaan Allah sudah datang kepadamu” (Lukas.11:20). Dalam konteks presentik maka Injil yang diberitakan Yesus langsung membawa sebuah perubahan pendengar atau penerimanya, dan pemberitaan Injil tersebut dapat berkaitan langsung dengan sebuah peran dan karya social manusia tersebut.

\section{Pemberitaan Injil dan Peran sosial}

Pemberitaan Injil biasa juga disebut pewartaan Injil yang dilakukan oleh Yesus Kristus ini yang seharusnya menjadi dasar pertama dan utama dalam pemberitaan Injil yang terus dikerjakan oleh gerja sepanjang abad. Dari pemberitaan Injil Kerajaan Allah yang dilakukan oleh Yesus Kristus Nampak sekali bahwa pemberitaan itu bersifat holistic dan komprehensif. Dalam Lukas 4:16-21 kita membaca contoh pemberitaan Injil yang dilakukan oleh Yesus Kristus di Nazaret dengan mengutip nubuat kitab Nabi Yesaya 61:1 tentang Mesias. Kita kutip mulai (ayat 17) KepadaNya diberikan kitab Nabi Yesaya dan setelah dibukaNya, Ia menemuka nas dimana ada tertulis: (ayat 18)" Roh Tuhan ada pada-Ku, oleh sebab Ia telah mengurapi Aku, untuk menyampaikan kabar baik kepada orang-orang miskin, dan Ia telah mengutus Aku (ayat 19) untuk memberitakan pembebasan kepada orang-orang tawanan, dan penglihatan bagi orangorang buta, untuk membebaskan orang-orang yang tertindas, untuk memberitakan tahun rahmat Tuhan telah datang". Ayat (12) Lalu ia memulai mengajar mereka kataNya:" Pada hari ini, genaplah nas ini sewaktu kamu mendengarnya".

Jelas sekali dari artikel ini bahwa Yesus yang adalah Mesias, datang memberitakan Injil (kabar baik) mengenai kerajaan Allah yang mencakup pembebasan rohani dan pembebasan jasmani. Kabar baik (eungelion) diberitakan tidak hanya dengan kata-kata, tetapi juga dengan perbuatan/tindakan social yakni menolong orang-orang susah. Yesus Kristus secara konsisten dengan pemberitaan Injil Kerajaan Sorga karena Ia selalu mewujudkan pemberitaan itu dalam peran social atau karya-karya social: menyembuhkan orang sakit, memberi makan orang-orang lapar, berbelas kasihan terhadap orang-orang lemah(tak berdaya),orang-orang terpinggirkan (kaum marginal), membebskan orang-orang hukuman atau orang buangan (berdosa)bahkan membangkitkan orang mati. Jadi kalau kita mendasarkan pemberitaan Injil pada pemberitaan Injil Yesus Kristus, yang adalah Injil itu sendiri, maka pemberitaan tersebut secara jelas terintegrasi melalui karya-karya social dari setiap orang percaya.

Benar bahwa memang dalam setiap gereja diajarkan adanya tiga tugas panggilan gereja yang dapat dibedakan berdasarkan arti dan maknanya, antara lain istilah koinonia, diakonia dan marturia. Tritugas panggilan gereja itu harus dipahami sebagai trilogy yang juga mengacu kepada Allah Tritunggal, yang merupakan satu kesatuan yang utuh, tidak bisa dipisahkan.'3 Dari ketiga itu hanya dapat dibedakan tetapi tidak bisa di pisahkan. Istilah marturia (dati kata martyr berarti saksi) hal ini dapat

3 Penjelasan tentang kesatuan trilogy tugas panggilan gereja, sudah dijelaskan oleh Arie de Kuyper, dalam buku Missiologi, yang pertama kali diterbitkan tahun 1968, Penjelasan mengenai kesatuan trilogy panggilan gereja dapat dibaca dalam pasal 21-22. Lihat: A de Kuyper, Missiologia, BPK Gunung Mulia, 1988,94-96. 
dimaksudkan sebagai kebenaran (Lukas 24:48); Kisahrasul 1:8,22) ${ }^{4}$ pemberitaan Injil secara verbal sebagai suatu testimony. Kata ini sering disebut juga' evangelisasi (Evanglization) artinya mewartakan Injil mengenai Yesus Kristus.'5 Satu bagian dari peristilahan ini, pemberitaan Injil sering diterjemahkan juga dengan kata misi (mission). Misi dapat selalu dimaknai dengan sebuah kata pengutusan dalam memberitakan/ mewartakan Injil.

Sebutan lain dari Pewartaanatau pemberitaan Injil adalah kata misi selalu dilihat sebagai kelanjutan dari Misi Allah ( Missio Dei) yang hadir didalam dan melalui Yesus Kristus (Missio Christi). Misi Kristus, sebagaimana di jelaskan diatas, yang berisi warta /berita gembira atau kabar baik tentang Kerajaan Allah yang mencakup seluruh aspek kehidupan manusia. Missio Dei sebagai pemberitaan Injil dimaknai sebagai partisipasi (gereja) dalam pengutusan oleh Allah.' ${ }^{\prime}$ Dalam hal ini misi gereja dapat dilihat sebagai tugas yang bersifat holistic atau komprehensif, sebagaimana misi Allah untuk membawah keselatan dan timur yang holistic dan komprehensif.

Bila memperhatikan dalam lingkungan gereja-gereja Ekumenikal, yaitu Dewan Gereja-Gereja se Dunia (DGD) atau World Council of Churches (WCC) dan Persekutuan Gereja-gereja di Indonesia, paham mengenai pemberitaan Injil sebagai misi gereja yang bersifat holistic, telah digumuli sejak tahun 1960-an.' ${ }^{7}$ Misi gereja adalah misi Allah yang ditujukan kepada dunia yaitu untuk membawa tanda-tanda syalom tentang kerajaan Allah.

Persekutuan Gereja-gereja di Indonesia sebagai lembaga ekumenis juga memahami Injil sebagai berita kesukaan yang sangat utuh dan menyeluruh, untuk segala makhluk, manusia dan lingkungan hidupnya serta keutuhanya: bahwa Injil yang seutuhnya diberitakan kepada semua manusia yang seutuhnya sebab Injil itu menyangkut keseluruhan kehidupan manusia, tidak hanya untuk kehidupan nanti di sorga melainkan kehidupan sekarang di dunia ini, bukan juga hanya mengenai jiwa atau roh manusia, tetapi juga mengenai keseluruhan kehidupan dan keberadaannya sebagai manusia, baik sebagai makhluk rohani, maupun sebagai makhluk politik, makhluk

${ }^{4}$ Gerald O' Collins dan Edward G Farrugia, Kamus Teologi, 191

5 Gerald O' Collins dan Edward G. Farrugia, Kamus Teologi, 76

6 Gagasan mengenai Missio Dei pertama kali daktulisasikan oleh Karl Barth dalam sebuah essay yang di bacakan dalam konferensi misi di Brandergburg tahun 1932 yang mengartikan misi sebagai suatu Aktivitas Allah sendiri. Dan tahun 1933, Karl Hartentein mengungkapkan keyakinan serupa. Tetapi menurut David J.Bosch pengaruh barth sangat menentukan sehingga ia dapat disebut sebagaieksponen yang yang menciptakan paham misi sebagai misi Allah sendiri (Missio Dei). Lihat David J. Bosch, TransformasiMisi Kristen, Sejarah Teologi Misi yang Mengubah dan Beruba, terj.Stephen Suleeman, Jakarta: BPK Gunung Mulia, 1997,597. Tetapi menurut siwu, Istilah Missio Dei diperkenalkan oleh Karl Hartenstein di Willingen tahun 1952 yang merupakan suatu ungkapan kesadaran baru tentang misi pasca Perang Dunia II dan Missio Dei dimaknai sebagai misi Allah di dalam dunia bukan misi gereja. Lihat: Richard A.D. Siwu,Misi dalam Pandangan Ekumenikal dan Evangelikal, Jakarta: BPK Gunung Mulia, 1996,196

7 Diskusi tentang misi gereja dalam Sidang Raya DGD tahun 1961 di New Delhi menggaris bawahi bahwa harus dipahami sebagai hakekat dari greja itu sendiri dalam wawasan tanggung jawab gereja dan peran gereja dalam bidang social dan politik. Lihat: Richard A.D. Siwu, Misi dalam pandangan......65. 
ekonomi, makhluk ilmu dan teknologi, makhluk kebudayaan, makhluk keamanan dan sebagainya.'8

Berangkat dari pemaparan di atas jelaslah bahwa pemahaman pemberitaan Injil, menurut gereja-gereja yang bercorak ekumenikal memahami pemberitaan Injil secara holistic dan komprehensif artinya pemberitaan Injil mencakup seluruh kegiatan yang menceritakan kebaikan-kebaikan TUHAN kepada umat manusia untuk menjawab pergumulan hidupnya dalam segala aspek yaitu rohani, jasmani, social, politik, ekonomi dan berbagai tekanan yang dihadapi umat manusia. Berita Injil yang diwartakan adalah berita pembebasan yang dilakukan oleh Allah melalui Yesus Kristus baik dalam aspek rohani maupun dalam aspek jasmani. Karena itu pemberitaan Injil tidak hanya diintegrasikan dengan pelayanan sosial, sebab karya social merupakan bagian integral dari pemberitaan Injil tersebut.

Pengertian ini tidak hanya dianut oleh gereja-gereja ekumenis tetapi dapat juga dipahami oleh gereja-gereja Injili (evangelical). Sejak ongres Evangelisasi se-Dunia di Lausanne tahun 1974, tanggungjawab social telah menjadi perhatian yang serius di kalangan Injili. Salah satu artiel dalam Lausanne Covenat yang merupakan hasil konfrensi tersebut menegaskan bahwa evangelism dan keterlibatan social dan politik keduanya adalah bagian dari kewajiban Kristen. Bahkan dalam dokumen itu juga diungkapkan semacam penyesalan atas sikap sering memisahkan evangelism dari tanggung jawab sosial.' ${ }^{9}$ Melalui hal ini kita juga dapat menemukan paradigma baru dalam memahami tugas pemberitaan Injil sebagai pelaksanaan misi Allah secara komprehensif. Dengan demikian tidak ada perbedaan yang sangat menyolok dari gereja-gereja dalam memahami kesatuan integral antara tugas gereja dalam pemberitaan dengan pelayanan sosial yang ada.

\section{Pemberitaan Kepada seluruh Makhluk hidup}

Untuk memahami pemberitaan Injil sama seperti yang tidak biasa maka patut di mengerti apabila pewartaan (kabar baik) tidak dapat dipisahkan dari tanggungjawab social, pemberitaan Injil juga tidak bisa dipisahkan dari tanggungjawab gereja terhadap lingkungan sekitarnya. Menurut teks Markus 16:15 biasanya menjadi landasan kitab suci yang memberi pamaknaan mengenai tugas pemberitaan Injil sebagai tanggungjawab gereja terhadap lingkungan sekitarnya. Justru, menurut Rom Elsadon, di Barat, orang tertentu menganggap tugas-tugas memelihara lingkungan hidup sebagian besar sama dengan tugas mengabarkan Injil kepada orang-orang yang belum pernah sama sekali mendengar Injil.'10 Melalui teks Markus 16:15 tentu tidak harus dipahami secara hurufiah, seperti misalnya yang pernah dipraktekkan oleh seorang yang benama Fransiscus dari Asisi, yang berkhotbah kepada burung-burung dan bunga-

8 Lih. buku: Lima Dokumen Keesaan Gereja Persekutuan Gerja-gereja di Indonesia,Jakarta: BPK Gunung Mulia, 1996, 22.

9 Lih. Richard A.D. Siwu, Misi dalam Pandangan....336. Band. David J. Bosch, Transformasi Misi Kristen,.....621.

10 Ron Elsdon, Green House Theology, Tunbrigdge Wells: Monarch Publication, 1992 194-195. Band. Borrong, Etika Bumi Baru, Jakarta: BPK Gunung Mulia, cet.4, 2009, 274. 
bunga. ${ }^{11}$ Memberitakan Injil kepada semua makhluk dapat ditafsirkan sebagai bagian dari tugas memelihara alam sekitar kita tetapi tentu saja tidak dalam arti pemberitaan secara verbal atau langsung.

Persekuatuan Gereja-gereja di Indonesia telah memahami Injil kepada segala makhluk ini dapat mengandung makna mengenai bagaimana tanggungjawab manusia sebagai penerima amanat dapat menjaga dan memelihara keutuhan ciptaan TUHAN. ${ }^{12}$ Jadi sama seperti tanggungjawab social gereja menjadi bagian penting dan utama yang perlu diperhatikan dan dilaksanakan secara serius dalam memberitakan Injil, demikian juga halnya dengan tanggungjawab manusia dalam memelihara lingkungan sekitarnya menjadi bagian integral dari pemberitaan Injil yang utuh. Injil juga tidak hanya dibawah oleh Yesus Kristus untuk memuliakan Bapa-Nya namun juga berarti dapat memberi pemulihan bagi kehidupan manusia dan seluruh kehidupan makhluk hidup lainnya yang ada di dalam dunia ini.

\section{Kesimpulan}

Dari seluruh refleksi diatas kiranya dapat menggiring kita pada judul artikel ini tentang hubungan pemberitaan Injil dengan tanggungjawab manusia dalam kehidupan sosial dan lingkungan hidupnya, yang salah satu klausanya menggelaisahkan kita adalah, "Tanggungjawab manusia dalam memelihara hubungan social dan lingkungan sekitarnya." Apakah melalui hal ini kita dipaksa untuk berpikir ulang tentang teologi social dan teologi misi kita? Gereja bukanlah satu-satunya alat vital untuk memberi respons yang paling tepat untuk menjawab banyak kesenjangan yang terjadi disana sini melinkan justru kita perlu dengan satu-satunya cara adalah ketika kita kembali meninggalkan mentalitas yang kerap membeda-bedakan golongan sosial dan lingkungan hidupnya dalam melaksanakan tugas panggilan mulia yang diemmbannya itu. Artinya bahwa tanggungjawab setiap orang percaya wajib memberi perhatian khusus pada kehidupan social dan lingkungan hidupnya dan harus menjadi bagian integral dari misi gereja yang utuh dan satu.

Dalam memproklamirkan berita sukacita atau kabar baik dari Allah yang telah dilakoni oleh Yesus Kristus sendiri dapat di estafetkan oleh gereja sepanjang masa dalam kapasitas yang terus maju dan berkembang sesuai dengan perkembagan zaman. Masa kini, persoalan ketidak adilan pengrusakan kehidupan social dan lingkungan sekitarnya merupakan ruang dimana Injil Kerajaan Allah harus diberitakan, dalam arti diwujudkan dan aktualisasikan dalam bentuk karya-karya social dan karya ekosofis. Injil tidak lagi hanya diberitakan secara verbal melainkan dilaksanakan untuk membebaskan manusia dan kehidupan social dan lingkungannya dari intimidasi dan penindasan serta pengrusakan. Demikianlah hakekat misi gereja masa kini yang sesungguhnya di Indonesia.

11 Roger Shorrel, St. Francis of Asisi and Nature, Oxford: University press, 1988, 68. Band. Borrong, Etika Bumi Baru, 190.

12 Lih. Lima Dokumen Keesan Gereja, Jakarta: BPK Gunung Mulia,1996, hlm. 25. 
Jurnal Luxnos Vol. 4, No. 1, Edisi Januari-Juni 2018

\section{Referensi}

Arie de Kuyper, Missiologia,Jakarta: BPK Gunung Mulia,1968,1988

David J. Bosch, Transformasi Misi Kristen, Sejarah Teologi Misi yang mengubah dan Berubah,Terj. Stepen Suleeman, Jakarta:BPK Gunung Mulia,1997.

Gerald O'Collins dan Edward G. Farrugia, Kamus Teologi

J.D. Douglas, Ensiklopedi Alkitab Masa Kini, Jilid I, Terj.Tim Penerjemah Yayasan Komunikasih Bina Kasih, Jakarta,2002

Lima Dokumen Keesan Gerejadi Indonesia, Jakarta: BPK Gunung Mulia,1996.

Richard A.D Siwu, Misi dalam Pandangan Ekumenikal dan Evangelikal, Jakarta: BPK Gunung Mulia,1996

Ron Elsdon, Green House Theology, Tunbridge Wells: Monarch Publication,1992

Roger Shorrel, St Francis of Asisi and Nature, Oxford: Oxford University Press,1988

R.P Borrong Ph.D, Etika Bumi Baru,Jakarta: BPK Gunung Muliah, cet.4, 2009. 